\title{
Economic and social impact of modernization on cultural values
}

\author{
Elena Andreeva \\ Urals State University of Economics \\ Institute of Economics (Ural branch, Russian Academy of Sciences) \\ Russian Federation \\ elenandr@mail.ru
}

Yuliya Myslyakova

Urals State University of Economics

Russian Federation

juljul@inbox.ru

\section{Pavel Glukhikh}

Institute of Economics (Ural branch, Russian Academy of Sciences)

Russian Federation

gluchib_p_l@mail.ru

\section{Artem Ratner}

Institute of Economics (Ural branch, Russian Academy of Sciences)

Russian Federation

aratner@inbox.ru

Abstract. Our paper focuses on the relevant theoretical economic approaches that allow us to understand the key elements of cultural values. The paper presents a model envisaged to estimate economic and social impact of modernization on cultural values in modern societies. We employ three indices of social and economic development for each level in Russian Federal districts of Moscow and St. Petersburg in order to reveal their impacts on modernization processes. Our data has been collected via the means of a questionnaire and an opinion poll with the purpose of revealing the value guidelines of society in terms of its modernization. Our results reveal the presence of four relevant levels of value orientations: family orientations, global, work, and personal orientations. Our results demonstrate how modernization is perceived in modern societies, in which spheres it is mostly expressed, and how it influences the society. Moreover, we show the determinants of values within four levels of value orientations. Our findings provide estimations of modern attitudes towards social consciousness in

Received: October, 2016 1st Revision: February, 2017 Accepted: April, 2017

DOI: $10.14254 / 2071-$ 8330.2017/10-1/14 
the processes of modernization and reveal basic moral principles that could become a background of new system of values used in modernizing modern societies.

Keywords: social values, cultural economics, modernization, cultural influence.

JEL Classification: Z13

\section{INTRODUCTION}

Cultural and economic values are one of managing elements of economic reality. Two models of economic reality show mutual dependence of the element "values" and other basic elements through the feedback existing between them that provides cyclical changes of fundamental elements. Namely, that happens as a result of a side influence of activity and of differences between a wish and a result. Value guidelines cannot change itself inside the sphere of values because this sphere is directed into the sphere of existence. The most important way of correction of own value guidelines and value positions in consequence of perception of results of own activity is a change of value scales (Yakovets, 2012).

Values influence directly any form of economic coordination because the higher rank of value modalities (signifying which carrier is a good) not only defines a perception of higher value qualities by potential users but also changes a way of use and correlation of scarcity of goods and services in general (Inglehart \& Baker, 2000; Gaweł , 2010; Čábelková \& Strielkowski, 2013: Balitskiy et al., 2014; or Novák \& Popesko, 2014).

The economic reality is being regulated not only by economic laws. Quite often, it is being defined by actions of people through their wishes and choices that form a whole set of economic expectations, social norms, cultural guidelines, and ethic imaginations about "good". Thence, it is determined by the values formed in the process of historical development of the society. Social and cultural terms of people communities shape up some life order, set moral norms, traditions, kinds of behavior, etc.

The complex that determinates the content and direction of social consciousness is called "cultural paradigm" and represents a fundamental vision of society which includes a complex of fundamental perceptions about the society and the individual of this historical period. Each social and historical epoch works out its own specific paradigm. The change of a paradigm goes hand in hand with the reconsideration of values, norms and guidelines, as well as of the system of weltanschauung (a particular philosophy or views of life) of people - a so-called "reevaluation of values".

Social and cultural values are often understood as the basic meanings of life by the individuals who are included in different forms of social activity or guided in their everyday lives (Štimac \& Šimić, 2012; Ustubici \& Irdam, 2012; Strielkowski \& Weyskrabova, 2014; or Abrhám et al., 2015; Bilan et al., 2015). These are the meanings that to a significant level determine the attitude of individuals towards the reality surrounding them as well as the basic models of social behavior of a human being. These values, on the one hand, are defined by the history and culture of a given nation, and on the other hand, are uninterruptedly passed from generation to generation (Koudelková et al., 2015). Literally speaking, values are social genes that define a structure and functioning of social organisms in which a nation lives and reproduces itself.

The changes happening in value imaginations can be understood only in the context of analysis of all system changes of society. Modernization changes of the $20^{\text {th }}$ century in Russia had a total, universal character, disseminating practically on all spheres of human life including a system of values, models of 
behavior and adaptation strategies of a personality. Modernization influences also welfare of population (Havrov, 2004; Arefiev, 2007; Zaslavskaya, 2011; Kuklin et al., 2011; or Kuklin \& Vasilyeva, 2015).

Orlova (2007) polemizes that in the $20^{\text {th }}$ century it become obvious that in a global scale social and cultural tendencies shaped up in developed countries and defined their leading position. They are being shown on the level of social organization of society. In the economic sphere, there is a movement from industrialism to post-industrialism. To them correspond changes in the areas of socially important knowledge and weltanschauung: so, in the art - from aspiration to the stylistic unity - to poly-stylistic; in the science - from objectivism to the anthropological principle. The total of these general social and cultural tendencies is taken to be called "modernization" (Orlova 2001).

\section{BASIC APPROACHES TO UNDERSTANDING OF BASIC VALUE ORIENTATIONS}

First of all, we should consider the most important theoretical approaches to understanding of basic value orientations that allows us to work out the model of estimation of social and cultural influence of modernization on value guidelines of society.

Kluckhohn \& Strodtback (1961) assumed that people during their life come into collision with one and the same problems and develop own system of value for the best solution of arising problems. Because the systems of values are the reflection of one and the same problems, that is why they are comparable.

As the most important directions of value orientations and their variations these authors mark out the follow: i) attitude towards nature: 1 - subordination to the nature, 2 - harmony, 3 - prevailing over the nature; ii) relations between people: 1 - on the basis of hierarchy, 2 - of group relations, 3 - of individual relations; iii) attitude towards social space: 1 - general, 2 - mixed, 3 - personal; iv) kind of activity: 1 - active action, 2 - contemplating, 3 - combination of "1" and "2". Further the results of this research were used and presented by Simonova \& Strovskiy (2003). We present their outline in Table 1 that follows.

Table 1

Variations of cultural variables

\begin{tabular}{|c|c|c|c|}
\hline $\begin{array}{l}\text { Attitude of human } \\
\text { towards nature }\end{array}$ & $\begin{array}{c}\text { Subordination to } \\
\text { nature }\end{array}$ & Harmony with nature & $\begin{array}{c}\text { Prevailing over the } \\
\text { nature }\end{array}$ \\
\hline $\begin{array}{c}\text { Relations between } \\
\text { people }\end{array}$ & $\begin{array}{c}\text { On the basis of } \\
\text { hierarchical relations }\end{array}$ & $\begin{array}{c}\text { On the basis of group } \\
\text { relations }\end{array}$ & $\begin{array}{l}\text { On the basis of } \\
\text { individual relations }\end{array}$ \\
\hline $\begin{array}{l}\text { Orientation on the } \\
\text { activity }\end{array}$ & $\begin{array}{l}\text { It is important to get } \\
\text { enjoy from the work }\end{array}$ & $\begin{array}{l}\text { Important by the work } \\
\text { is a process }\end{array}$ & $\begin{array}{c}\text { Important by the work } \\
\text { is a result }\end{array}$ \\
\hline $\begin{array}{c}\text { Orientation inside of } \\
\text { time }\end{array}$ & To live in the past & To live in the present & To live in the future \\
\hline $\begin{array}{c}\text { Orientation in social } \\
\text { space }\end{array}$ & As a part of the society & $\begin{array}{c}\text { Mix of individualism } \\
\text { and belonging to a } \\
\text { system }\end{array}$ & As a separate person \\
\hline
\end{tabular}

Source: Simonova \& Strovskiy (2003)

The useful classification of values and kinds of activity was proposed by Simonova \& Strovskiy (2003) who marked out follow types of a human:

- theoretical (estimates the finding of truth);

- economic (estimates that, what is useful);

- esthetic (estimates a beauty and a harmony);

- social (estimates altruism); 
- religious (estimates uniting with cosmic space).

One of the most comprehensive among the descriptions of differences between national cultures is a research of Hofstede et al. (1990) who analyzed 117000 questionnaires from 67 countries and proposed 4 most important dimensions of culture outlined below:

1) Distance of power. This variable means a degree of inequality between people, that is counted by a population of certain country as normal. The low index speaks about relative equality in the society, the high - vice versa. In organizations, this index shows the hierarchy of management, the degree of centralization and participation of employee at making decisions. Companies, where this index is high (the majority of African, Asian and Latin American counties as well as France, Belgium, Italy and Spain) are usually more centralized and less admit their employees to making decisions. In such cultures, employees can get afraid of the type of management, that doesn't correspond to their cultural environment. In the countries with a small distance of power the activity of companies with high degree of participation of employees at making decisions will be more effective.

2) Individualism - collectivism. This dimension shows, how much people of certain society feel themselves more as independent individuals or members of a group. High index is observed almost by all countries with high level of life; vice versa, a low - by poor countries. The high degree presupposes, that the human cares for him(her)self and his/her folks, as well as is responsible for all own actions. In collectivistic societies since the childhood is being cultivated by people the respect to the groups, to those they belong. Members of a group expect that the group protects them and will take responsibility for what they owe to pay by loyalty in their relations to the group. In the organizations, individualism finds expression in autonomy of employee, his/her personal responsibility for results of activity and in a reward for his/her personal contribution.

3) Masculinity - femininity. These two poles reflex, how people of certain culture relate: to values like persistence, success, competition, self-confidence, that are being associated in the big degree with a role of a man; and to values like modesty and care, keeping warm relations, that are being associated with a role of a woman. The society is characterized through a male basis, if it is strongly oriented on effectiveness, success and self-confidence, don't excluding proneness to conflict and negative attitude towards personalities with distinctive behavior. Female culture pays more attention to inter-personal relations, preserving the environment, is targeted on compromise decisions and estimates cooperation. In organizations, this criterion finds reflection in the based on personal merits possibilities of getting of a higher salary, acknowledgment, career growth.

4) Aspiration to avoid uncertainty. This variable (index of lowering of uncertainty) can be defined as a degree, with that people of any country prefer structured situations in opposition to unstructured. In the first way exist clear and precise rules how should everybody behave. In the countries with a high aspiration people have a tendency to demonstrate a higher excitement and trouble, feverishness at job. In these countries prevails the opinion that all, what is not "us" and unaccustomed is dangerous; otherwise it wakes interest and is being characterized through tolerance towards other opinions and habits. So, in the countries with high degree of overcoming of uncertainty, a company, in that the rules are precisely defined, will be more effective; in the countries with low degree of this index it is needed more freedom of action for getting higher results. 


\section{BUILDING MODEL OF ESTIMATION OF SOCIO-CULTURAL INFLUENCE OF MODERNIZATION ON VALUE GUIDELINES OF SOCIETY}

By carrying out opinion poll it was proposed by us to estimate a potential influence of modernization according to four vectors (indexes) mentioned by the 8-point-scale.

Taking in account an active development of processes of globalization and neo-economics on all sides of social life, in the methodical context it was marked out by us the following 4 levels for the estimation of socio-cultural influence of modernization on value guidelines of society: global, national, local and individual. The idea of classifying of values into levels is present by many researchers, for example (Bolten, 2012, p. 21).

The model worked out by us (Figure 1) pre-supposes the search of optimal zone of crossing of four levels, or four value orients, marked out:

- oriented on the development of personal life, type A - so called comfortable life. In this way is meant a country's level, because a family is the primary cell of society and allows to solve the most important for country's development and nation's existence problem - demographic;

- oriented on the development of our common home - planet, type B - so called full life presupposing a possibility of maximal involvement of ecological guidelines into own personal guidelines;

- oriented on development of career or of kind of activity, type $\mathrm{C}$ - active life presupposing the main accent in value guidelines on the advance on the job. In our way, it is equated with a local level, because solves the most important for this level problem of employment;

- oriented on development of personality, type D - so called interesting life presupposing a spiritual and personal growth of an individual as a main orient.

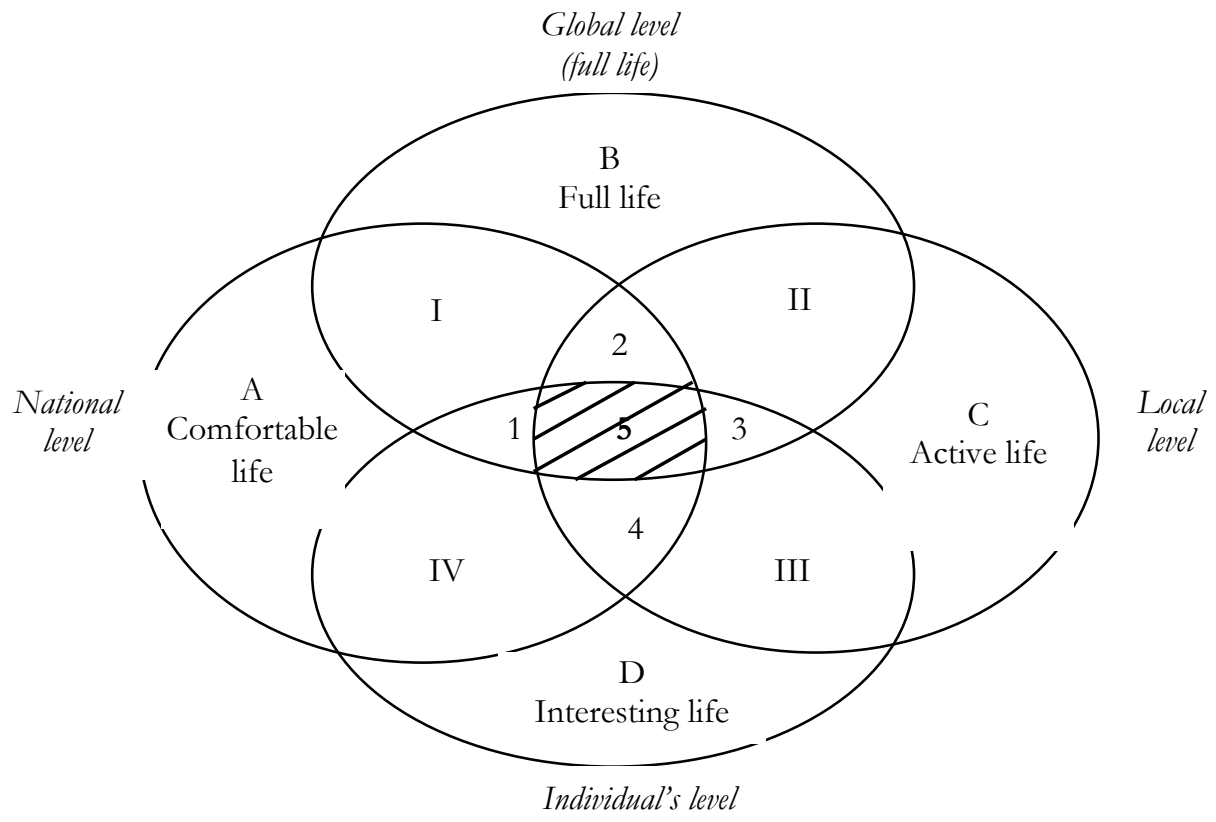

Figure 1. Model of estimation of socio-cultural influence of modernization on value guidelines of society

If these four levels will be presented graphically, we get different kinds of crossings:

I - crossing of A and B: family and rest; 
II - crossing of B and C: job and rest;

III - crossing of $C$ and D: raising professional qualification;

IV - crossing of A and D: help and self-development;

as well as crossings of three levels:

1 - crossing of $\mathrm{A}, \mathrm{B}$ and $\mathrm{C}$ : interest to new opportunities providing many-sided development of personality and self-realization of a person both as an individual and a family man and as a human with a principle "planet is our common home";

2 - crossing of A, B and C: understanding and use of global opportunities as a connecting link between achievements in private life and at a job;

3 - crossing of B, C and D: education, rise of qualification and having command of foreign languages allowing to realize own career and status destination;

4 - crossing of A, C and D: harmonious development of personality presupposing finding of optimal balance between family and job.

As a result, crossing of all four levels we get the figure 5 , into the definition of that we put an ideal state of value development - harmonious development of personality on basis of the newest achievements of science and education with a combination of the best achievements of world culture and civilization.

The basic values highlighted by us for each of four levels are presented in the Table 2 .

Table 2

Values being considered on four levels of the model

\begin{tabular}{|c|c|c|c|}
\hline Personal life & Common planet & Job & $\begin{array}{c}\text { Development of } \\
\text { personality }\end{array}$ \\
\hline Humanity & Honesty & $\begin{array}{c}\text { Intention to achieve a } \\
\text { target }\end{array}$ & Ability to be taught \\
\hline Wish to make a good & Fairness & Effectiveness & Realizing of destination \\
\hline Ability to love & Patriotism & Professionalism & Communicability \\
\hline $\begin{array}{c}\text { Understanding of } \\
\text { beauty }\end{array}$ & Freedom & Enterprise & Personality growth \\
\hline Sincerity & Tolerance & Persistence & Trust in oneself \\
\hline Politeness & $\begin{array}{c}\text { Respect to foreign } \\
\text { standards }\end{array}$ & Cooperation & Independence \\
\hline Respect & Trust & Devotion to the affair & Responsibility \\
\hline Mutual understanding & Logic of thinking & Innovation & Creativity \\
\hline $\begin{array}{c}\text { Intention to be } \\
\text { economical }\end{array}$ & Breadth of thinking & Imagination & Acknowledgment \\
\hline Patience & Readiness to help & $\begin{array}{c}\text { Intention to be } \\
\text { industrious }\end{array}$ & Optimism \\
\hline
\end{tabular}

Source: Own results

According to the 4 levels of the model developed are revealed the factors, influencing the modernization carrying out: global level includes such factors as foreign trade, foreign capital and international migration; national level - fixed investments, small enterprises activity and transportation of goods; local level - gross regional product, economy's structure, provision by resources; individual's level average annual number of employed, release of specialists with higher education and expenditures on research and development. It seems to be relevant to reveal by means of econometric model, in what extent the success of modernization is related on these four levels (1). 
$y(x)=f\left(A\left[x_{1 A}, x_{2 A}, x_{3 A}\right], B\left[x_{1 B}, x_{2 B}, x_{3 B}\right], C\left[x_{1 C}, x_{2 C}, x_{3 C}\right], D\left[x_{1 D}, x_{2 D}, x_{3 D}\right]\right)$, where A - global level, B - national level, C - local level, D - individual's level.

At that the modernization process is expressed in the form of producing the innovative goods, works and services. To reveal the correlation, it is taken one region of each Russian federal district, and also separately - Moscow and Saint-Petersburg. In accordance with the Cheddok-scale for classification of relation power, the correlation coefficient of 0,1 to 0,3 reflects slow relation power, of $0,3-0,5$ - moderate, of 0,5-0,7 - noticeable, of 0,7-0,9 - high, of 0,9-0,99 - very high (table 3).

The analysis showed that the averaged correlation coefficient (among all the above regions), the first and second places were taken by local-level factors - GRP and the volume of shipped goods in the manufacturing sector (it indicates the use of innovation in the real sector and the implementation of the planned neo-industrialization strategy at the regional level. The third place went to the level of the individual factor - domestic expenditure on research and development (which is natural), the fourth place - such factors as the level of the national turnover of small enterprises Fifth place went to factor global level international migration.

The main capital investments are in the sixth place at the average correlation coefficient (national level), which suggests that modernization is an important national priority, and the company invest in the modernization of production.

Most often, high correlation coefficients are met by Moscow and St. Petersburg, being economic and financial center, where the focus offices of large companies - for foreign trade and domestic spending on research and development, and investment in main capital (Moscow) and the volume of production in the manufacturing sector (St. Petersburg). By the turnover of small enterprises, as well as by other indexes, are to mark out the Kursk and Nizhny Novgorod regions located near to these central regions, as well as Omsk region. Khabarovsk region has a high coefficient by goods transportation, what corresponds to its geographic location, to importance of transport factor for its economy.

It is remarkable that the release of specialists with higher education does not have a high coefficient of statistical relation with volume of innovative production; it's related on the decrease of birthrate in Russia in 1990s, when it was an economic crisis.

Its characteristic that foreign direct investments, as the correlation analysis shows, almost don't influence the growth of the innovative goods volume, what testifies that foreign investor contributes more not to manufacturing industry, but to the mining. That's why the gamble is set in the economy more and more on internal sources in investing.

Thus, the correlation analysis has shown that by a number of factors the relation power in a number of cases is very high, in particular, it relates on the turnover of small enterprises and on foreign trade turnover. It says that the prospects of support of export of the small entrepreneurship, including of the export-oriented, are the engine of innovative economic growth and stimulate the working out and the applying the new technologies. 
Table 3

Results of approbation of the econometric model for Russian regions

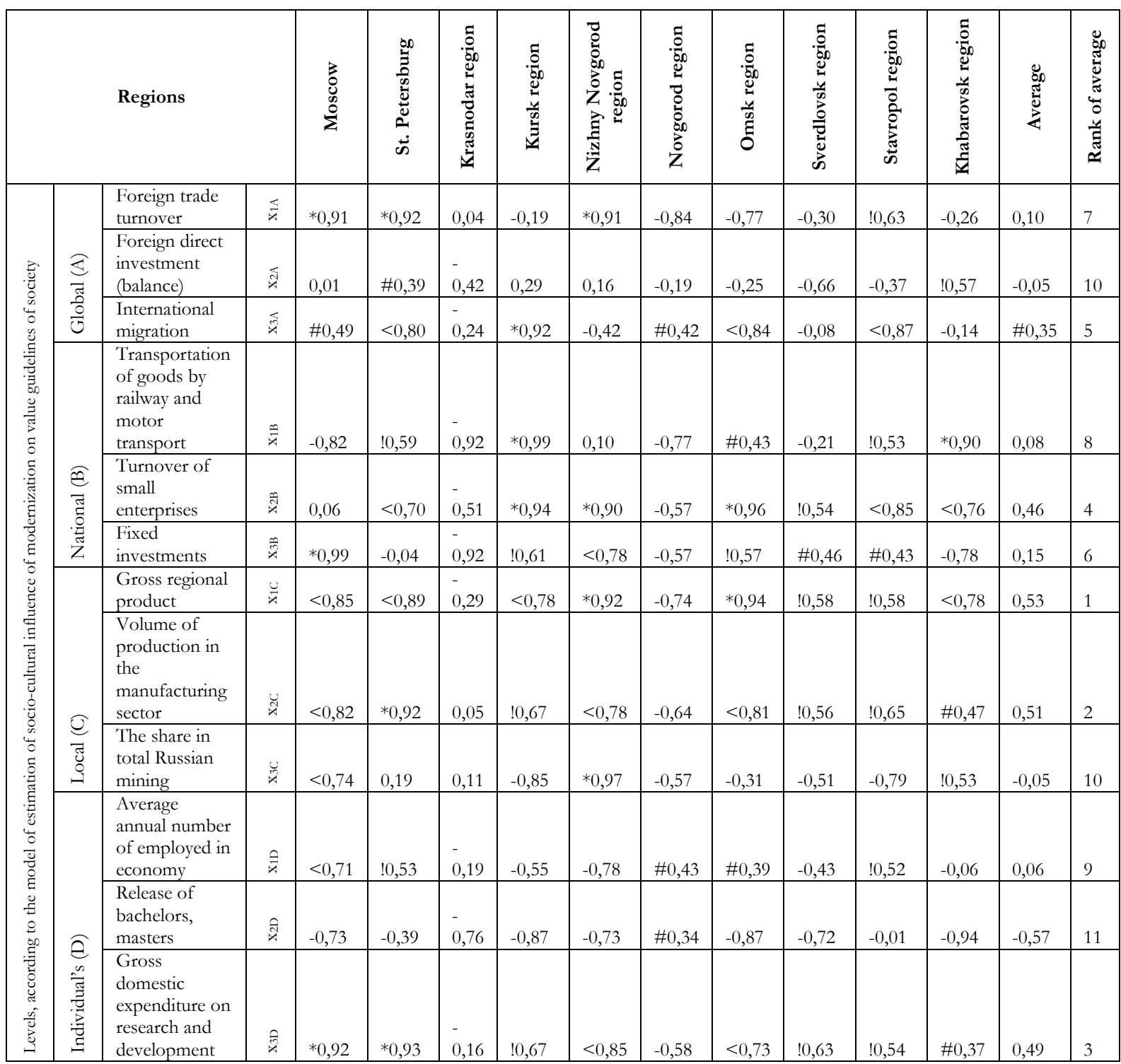

Note: The correlation with the index of foreign direct investment balance is calculated for the years 2011-2014, due

to the fact that the statistics presented in 2011, correlation with the index of turnover of small enterprises is calculated for 2009, 2010-2014, because that the statistics 2010 is not presented; "*" it happens of very high relation power; "<" - high relation power; "!" - noticeable relation power; "\#" - moderate relation power.

Source: Own results

\section{APPROBATION OF THE MODEL OF ESTIMATION OF SOCIO-CULTURAL IMPACT OF MODERNIZATION THROUGH AN OPINION POLL}

We carried out an opinion poll of representatives of local community of traditionally industrial Ural region (Russia) - students and staff of universities, representatives of enterprises, of authorities. Carrying 
out questioning supposed ranking of values for respondents and so marking out the most important (the most emphasized or got the highest mark) for each level.

In the process of the questioning $61,9 \%$ of respondents marked out that modernization on territories of their living is actively demonstrated, $29,8 \%$ count that it is not strongly noticeable, $8,3 \%$ of respondents don't see its expression.

Thereby, only 15,5\% of respondents reckon that costs for currying out modernization are justified. About $65,5 \%$ of respondents agree that these costs are particularly justified; and 19\% don't see the justified relation of costs and results. According to the opinion of $79,8 \%$ of respondents, the society pays not enough attention to the problem of modernization; $17,9 \%$ count, that enough, and $2,3 \%$ - count, that even too much.

Basic spheres, in those, according to the opinion of respondents, the modernization is the most expressed, are allocated as follows: on the first place - appearance of new shops and cafes $(22,7 \%)$, on the second - constructing of dwelling houses $(17,1 \%)$, on the third - education $(9,1 \%)$.

In the sphere of public health service the process of modernization is marked by $6,3 \%$ of respondents, in housing and public utilities - by $6,3 \%$, in building of cultural objects - by $4,5 \%$, on transport - by $2,8 \%$. In the sphere of production and its reequipment the modernization is marked only by 1,1\% of respondents.

As for criteria of culture outlined by Hofstede (Hofstede et al., 1990), according to the 8-point-scale, where " 1 " characterizes centralization and " 8 " - decentralization, is marked the shift to the decentralization (28,9\% of respondents gave the mark " 4 " and $26,5 \%$ - the mark "5"). According to the index of individualism (1) - collectivism (8) by high middle shares also is high the gravity of those respondents, who prefers individualism (mark " 1 " by $9,6 \%$ of respondents). In the index of masculinity (1) - femininity (8) however dominates the intention to loyalty and finding of compromises $(24,4 \%$ of respondents chose the mark " 5 "). In the intention to avoid uncertainty is noted its high index $(28,9 \%$ of respondents chose the mark "4").

In such direction of value orientations as attitude towards nature, almost $2 / 3$ of respondents count that modernization lead to "the predominance over the nature" and only $1 / 3$ find their attitude as harmonious. In relations between people modernization, to the opinion of a half of respondents, raises the importance of group relations, and, to the opinion of $1 / 3$ of respondents, - of individual relations. As for social space, more than a half of respondents, and exactly 56,6\%, count, that modernization leads to the mixing of common and personal space. The same picture is observed by the assessment of influence of modernization on a kind of activity: the same share of respondents marks the necessity of combination of active action with contemplation.

To use achievements of modernization in the most degree one can, according to the opinion of $1 / 3$ of respondents, first of all, apply a so-called "economic type" of human who values what is useful or her/him and what is not. About 8,6\% of the respondents consider that esthetical and social type values include beauty and a harmony. It is interesting that theoretical type valuing finding of truth was selected only by $4,1 \%$ of respondents, which in terms of innovative economy, of course, confines getting of the most possible effect from eventual success of modernization.

As for the importance of values in a private life, among 10 values offered, the highest marks were attributed to mutual understanding $(10,4 \%)$, humanity $(9,6 \%)$, ability to love $(7,7 \%)$. The lowest marks were attributed to beauty $(0,6 \%)$, politeness $(1,3 \%)$ and scarcity $(1,7 \%)$ which explains enough about the philosophical understanding of life, however also about low level of estimation of practical and useful qualities which we use every day. 
Among the values in the part "planet - out common house" the first places were occupied by such values as "readiness to help" $(6,0 \%)$ and "fairness" $(5,9 \%)$. The lowest marks have got such values as "logic of thinking" (1,6\%), "trust" (1,9\%), "breadth of thinking" (2,7\%). Almost the same shares have got values "patriotism" (2,7\%) and "freedom" (2,9\%).

In the sphere "job" the first places went to the following values: "professionalism" (5,9\%), "intention to achieve a target" (4,7\%), "effectiveness" (4,0\%). Unfortunately, "an enterprise", "persistence", and "imagination" were marked by the smallest quantity of respondents $(0,8 \%, 0,7 \%$ and $0,7 \%$ accordingly). "Innovation" was emphasized by $2 \%$ of respondents, and "intention to be industrious" - by $3,4 \%$.

In the personal development, the first places were taken by communication skills $(3,9 \%)$, responsibility $(3,8 \%)$ and learning ability $(2,5 \%)$. Less respondents chose: recognition $(0,4 \%)$, realization of destiny $(0,7 \%)$, creativity $(1,2 \%)$. It definitely does not allow to use fully the potential for the development of the modernization process.

About $79,3 \%$ of respondents answered that they felt an interest and willingness to learn a new technology when they met across something new. The willingness to improve the technology appears just among $1,2 \%$ of respondents. This demonstrates the willingness to be the consumer of the results of modernization more than to be an active participant. All in all, the understanding and perception of the modernization processes are summarized in Table 4.

Table 4

The general perception of the modernization process of the local community

\begin{tabular}{|l|c|}
\hline \multicolumn{1}{|c|}{ Possible answer } & $\begin{array}{c}\text { Percentage of } \\
\text { respondents, in } \\
\text { \% }\end{array}$ \\
\hline Modernization brings to the culture of society new, useful qualities & 11,7 \\
\hline Modernization brings new technologies into all areas of human activity & 29,8 \\
\hline Modernization promotes the development of technology, but not humanity & 12,2 \\
\hline Modernization destroys the traditional culture of the society & 3,4 \\
\hline Modernization enhances antisocial (abnormal) phenomena in society & 2,9 \\
\hline
\end{tabular}

The majority of respondents (nearly 30\%) connect modernization with bringing new technologies into all areas of human activity, while $13 \%$ considers that the contribution of the modernization is in the development of technology, but not humanity and yet $11 \%$ think that modernization generally brings useful qualities in the culture. A small amount of respondents $(4,2 \%$ и $3,5 \%)$ mark the negative effect of the modernization process.

\section{INTERPRETATION OF THE RESULTS OF A SOCIOLOGICAL SURVEY: SOCIO- CULTURAL INFLUENCE OF MODERNIZATION IN RUSSIAN SOCIETY}

Modernization is a vector change of the socio-cultural sphere, decrease of local and increase of universal components, megatrend from localism towards universalism. Modernized society mostly relates to countries of Western civilization and societies in the final stages of the modernization process. Market economy, private property, exchange, competition, hired labor, profit are dominating in human society. Universal component includes rules, values and behavioral models. The movement towards universalism in many respects is identically to the movement to liberalism in economy and society and to the domination of rational worldview. 
The process of forming the values of highly developed countries of the West (such as private property, human rights [14], competition, competitiveness, lasted for two hundred years and withstood the test of time. These values are included in all aspects of the life of the human society (e.g. economics, ethics, or morality) and they become an integral part of the Western world view. However, it might be that the values in Russian society are not the same. The modernization processes that lasted for two centuries in the West failed to establish Western values such as individualism, private property and the Protestant work ethic in Russia. A traditionalist consciousness and its features such as collectivism, commitment to equalization, the condemnation of wealth provided the most active resistance to the reforms.

Modernization processes in Russia have a deep specific character connected with the fact that there is a differentiation of society. A variety of values has turned not only in the conflict of values, but the conflicting clash of civilization types. The civilization dualism of Russian society (differentiation according to civilization preferences between the modernization elite and the rest of the population) generates contradictions that slow down the process of modernization.

Thus, modernization process in Russia is going in a conflict of values and in a deep socio-cultural division. It was defined in a big part through the change of economic system. This is also typically for previous socialistic countries like east part of Germany, what emphasize such German researchers like Bolten \& Dathe (1995). The ideals of the old values and norms of the socialist economics are partly forgotten. But some ideas that have reasons in cultural archetypes, are strongly held in the traditional consciousness:

- the need to live in all-powerful state;

- longing for strong leader;

- desire of equal distribution;

- absence of likings for entrepreneurs.

On the other hand, values of the modern market society are introduced slowly, coming across strong resistance from the people. Related on this the absence of serious basis for market ideology that can unite ideas of modern society whose basic values will be economic efficiency and rationality, free enterprise and private property, provides modernization process with threatening character and poses a number of challenges not only to the elite of modernization, but also to society as a whole.

Russian citizens have their dual character national mentality. For example, many Russians support market economy, and at the same time welcome the idea of a "strong hand." The mixed, even contradictory character of consciousness will be testified by two basic models of value system. On the one hand there is a postindustrial, individualistic model of Western sample, on the other hand - patriarchal-collectivistic system of values, that is more typical for the national consciousness.

The change in the value system of Russians was an attempt to adapt to the new conditions of life. Material well-being dominates in the hierarchy of values. Materialistic pragmatic values start to displace moral values that were characteristic for Russian mentality. In the system of values first places were taken by "family", then "income", after that "interesting work", "quiet life" and "conditions for creativity". This statement is especially common for young people. Around $40 \%$ of young people approve the aspiration for "making money" at any cost, even with breaking the law. $60 \%$ agree that "today there are no dishonest ways to make money, there are only light and difficult pathways" (Ivanov, 2004).

Social behavior is increasingly determined not by moral criteria but the momentary circumstances of material gain. The transformation process in Russia is complex and controversial according to the one-sided understanding of liberal economic values: freedom in economics, equality of opportunities, human rights, 
private property, the market. Liberal values in Russia have transformed together with the rejection of the most important components of Western culture - namely, Christian labor ethic and personal responsibility.

It can be said that modernization process had not happened, but there was the process of borrowing fragments of another cultural experience. New values themselves do not cause rejection of the majority of people, although they conflict with the former Soviet value preferences - public ownership, social equity, fairness and teamwork. At the same time reorientation from the work values to consumer values, permissiveness as an indication and consequence of the fall of public and private morality, significant reduction in life-meaning aims and motives of activities cause a sharp rejection at the majority of people. In this connection, an imbalance between values and interests has appeared and the relationship between people has tightened.

Thus, in the process of transformation of Russia two value systems conflicted with one another liberal, which replaced the socialism, and traditional that has been developed for many centuries and changes of generations. The negative feature of the traditionalism is conservatism, and as for liberalism its main feature is a destructive character of the soulless competition (Allard, 2002).

The reason of this conflict is the unavailability to become innovative in Russian society. Building the new type of society requires the adaptation of new ideals, behavior models, communication rules, work motivation by each individual. Not all the Russians are able to solve this issue. This became the reason for the division on those who are capable for innovative behavior and those who cannot learn it.

\section{OPPORTUNITIES OF THE DEVELOPMENT OF VALUES IN RUSSIAN SOCIETY DURING MODERNIZATION PROCESS}

The basis of the new system of values can be built on base of moral principles, common for many countries of modernized society:

- respect for the person. Anyone has an absolute value to the community irrespective of material wealth, or any other indicator;

- respect for the labor. Only socially productive labor aimed at strengthening the material and spiritual well-being of the whole society, can become the basis for the social rising of the person and gaining public recognition;

- respect for the profession and knowledge. Through successful learning and the acquisition of knowledge everyone can conquer a decent position in society;

- respect for moral values (Andreeva et al., 2016). The principle of "Not by Bread Alone" emphasizes the universal significance culture and morality, without them there could not be any social program. Economic expediency may not violate the boundaries of morality;

- limitation of needs (reasonable minimalism). With existing environmental issues and increasing numbers of economic crises reduction of the rate of consumption should become an ethical position that contributes to the accumulation of social energy and to overcome the crisis on public and individual levels;

- respect for social justice. This includes the respect for the law and the proportionality of the distribution of wealth and other awards.

Historical experience shows that the successful development of society is usually possible due to evolutionary complement of values and integration of positive properties, but not the confrontation. Social and cultural values synthesize preferences of social groups that are formed under the influence of people's new needs and according to achievements of the previous development of Russia and world community.

The methodical approach developed and the assessment model proposed, and also its testing on industrial areas of the Urals, Siberia and the Far East, allowed to substantiate recommendations for forming 
the strategy of optimization of socio-cultural influence of modernization on forming the value guidelines on four levels: global, national, local and individual level.

An important lesson of the modernization projects is that only appeal to really relevant values can be successful.

The majority of modernization projects are linked to the basic change from traditional to modern society. This change is associated with strong macro-social stresses that appear as a result of reducing the role of the traditional society and intentional transformation, including modernization projects. Other macro-social conditions of realization of modernization projects are also connected with this issue.

As noted above, the transformations are connected with the decreased regulatory role of norms and traditions, and, ideally, with the gradual development of modernized mechanisms of macro-social regulation, based on universalistic values and personal rational choice. In other social conditions, tensions can be created by the decline of the regulatory role of previously learned universalist values and by the decline of the general social integration.

The appearance of transformational tensions is connected with the detail, that the decreasing regulatory role of norms and traditions and the strengthening role of universalist values often happen asynchronously and without saving the overall level of social integration and macro-social regulation. Even in the history of Russia, when the process of changing the mechanisms of social regulation had been carried out during a very long time, "step by step", capturing elite groups at first and then increasing masses, there was a sufficiently long period of overall weakening of macro-social regulatory mechanisms. Society interprets this situation as the religious or moral crisis.

This contradiction to modernization puts an additional constraint on the nature of our developing modernization project. The restriction underlines our focus on consistent improvement of the situation, avoiding long periods of deterioration that undermine the social support of the reforms.

Also, clashes of tradition and progressivism should be avoided. It is relevant to avoid projects that can be offensive for the values of significant social groups during the modernization project. For example, by the reform of "monetization of privileges" many members of the older generation decided that it was an attempt to "monetize" the meaning of their life sense. Effective tools in such cases are social and ethical expertise, public surveys and expert assessment.

On each stage, it should be taken special steps to increase social support, to "drag" neutral, but ready for adaptation groups of people on the position of supporting the reforms. Thence, modernization projects should be realized during the formation of the appropriate support. It imposes serious restrictions on the rate of change. However, the seeming delay is more effective than getting into a vicious circle: "Reform counter--reform".

Socially and nationally responsible modernization requires a huge social tact and permanent monitoring of the social support of the reform. It should not be limited only by the study of public opinion. Important is a deeply penetration into the mechanisms of social support with the marking out of the active support position and passive-neutral position.

In spite of all these limitations, the existing social conditions provide sufficient opportunities for realization of the large-scale project of national modernization, able to solve the key problems of the country and to respond to internal and external challenges facing Russia.

In order to increase the positive impact of socio-cultural factors on the formation value guidelines of local communities of industrial areas it is required to identify the strengths and weaknesses of this process based on the developed model. The suggested recommendations are selected in terms of view of economic efficiency, and presented are only those that require for the implementation the lowest cost, and usefulness 
of the effect is the largest. According to the model of estimation of socio-cultural influence of modernization on value guidelines of society are prepared recommendations on four levels:

1) on individual level (the improvement and modernization of the values of reproductive behavior of individuals);

2) on local level (development of labor and entrepreneurial potential and improving the management of labor and social system on the local territory);

3) on national level (increasing innovativeness of the national economy);

4) on global level (international scientific and technological cooperation).

Depending on the degree of socio-cultural factors, these recommendations can be aimed at the formation of the creative value guidelines of local society and can suggest a corresponding set of measures.

\section{CONCLUSIONS}

To sum up, the following key points can be mentioned: Firstly, it is necessary to consider that the transformation of the world development accelerated significantly and acquired new features associated with global change in the balance of economic power in the world.

Secondly, values are considered to be a factor of direct influence on the form of economic coordination. Social and cultural values play an important role in this context. Social and cultural values are basic life meanings and people use them as guidelines in their everyday lives. Values largely determine the attitude of individuals to the reality around them and determine the basic model of human social behavior.

Thirdly, the need of modernization has a particular importance for our research. Modernization theory was developed in the framework of the universal tradition of Western liberalism, where all countries and nations pass the same stages during their development. So, the modernization was developing as a universal process. Experience of different countries shows that modernization is impossible or possible but at a very slow pace without the transformation of institutions and culture.

Fourthly, the announced shift to an innovative economy in Russia should be based on the structural change at the local level, the reallocation of information and resource flows, the creation and strengthening of local systems and regional growth centers, corresponding to the value orientation of society. It is important to make identification, description and stratification of the basic types of local systems functioning in the innovation space. Stratification is the process of forming local systems according to their function, significance, subordination, that determine the place of each local system in their relationship. Also, openness, interaction and mutual influence of major local systems of the world community should be supposed.

Fifthly, the most important methodological approach in estimation of social and cultural influence of modernization on value guidelines of society in industrial area is the socio-economic approach. This approach includes consideration of the social and economic impact of technological development, organization of effective social partnership and the formation of social responsibility for decisions. The implementation of this approach may become a determining factor in socially-oriented technological development of local socio-economic system, a reserve of improvement of the well-being of the population.

Sixthly, our model supposes a search of the optimum range crossing of four levels or four value guidelines: i) the development of private life - comfortable life. In this case, it means the country level, because family is the basic unit of society and can solve the most important issue for the development and the existence of the nation - the demographic question; ii) the development of our planet - so-called full life, that presupposes the involvement of ecological guidelines into personal guidelines of people; iii) career 
development - the active life, which implies moving up the career ladder. In our case, this is equal to the local level because it can solve an employment problem for this level; 4) personal development - the socalled "interesting" or "meaningful" life, for which the basis is the personal growth of the person.

Seventhly, our innovative questionnaire survey showed that the process of modernization in contemporary Russia happens in a conflict of values and in a deep socio-cultural division. The ideals of a socialist economics are abandoned and partly forgotten, but some ideas are held in the traditional consciousness.

Eighthly, the recommendations are prepared on four levels according to the model of estimation: a) on individual level (the improvement and modernization of the values of reproductive behavior of individuals); b) on local level (development of labor and entrepreneurial potential and improving the management of labor and social system on the local territory); c) on national level (increasing innovativeness of the national economy); and d) on global level (international scientific and technological cooperation).

In conclusion, we can sum it up as follows: for the successful modernization process one needs a certain hierarchy of basic values. Fundamental values should be evidences not only of the society's readiness for changes and the desire of a sufficient number of social groups to undertake the task to become the subjects of changes but also of a rather realistic view on aims of the movement and the ways to achieve them.

\section{REFERENCES}

Abrhám, J., Bilan, Y., Krauchenia, A., \& Strielkowski, W. (2015). Planning horizon in labour supply of Belarusian small entrepreneurs. Economic Research-Ekonomska Istră̌ivanja, 28(1), 773-787. doi: https://doi.org/10.1080/1331677X.2015.1084238

Allard, E. (2002). Doubtful advantages of the concept of modernization. Socis, 9.

Andreeva, E. L., Myslyakova, Y. G., Karkh D. A., Loginov, V. G., \& Ratner, A. V. (2016). Evolution of social responsibility of economic entities. In: SGEM 2016: Proceedings of 3-rd international multidisciplinary scientific conference on social sciences and arts. Economics and tourism. Sofia, Book 2, 5, 237-244.

Arefiev, I. (2007). The transformation of socio-cultural values in the modern Russian society in the conditions of transition to market relations. The humanities and socio-economics, 4.

Balitskiy, S., Bilan, Y., \& Strielkowski, W. (2014). Energy security and economic growth in the European Union. Journal of Security and Sustainability Issues, 4(2), 125-132.

Bilan, Y., Cabelkova, I., \& Strielkowski, W. (2015). State taxes and cultural values: Evidence from the microeconomic data. Aktual'ni Problemy Ekonomiky= Actual Problems in Economics, 164(2), 108-116.

Bolten, J. (2012). Interkulturelle Kompetenz, rev. Ausg, Landeszentrale für politische Bildung, Thüringen, Erfurt.

Bolten, J. (Ed.). (1995). Transformation und Integration: aktuelle Probleme und Perspektiven west-/osteuropäischer Wirtschaftsbeziehungen (Vol. 2). Wissenschaft \& Praxis.

Cábelková, I., \& Strielkowski, W. (2013). Is the level of taxation a product of culture? A cultural economics approach. Society and Economy, 35(4), 513-529. doi: https://doi.org/10.1556/SocEc.2013.0007

Gawel, A. (2010). The Relationship between Entrepreneurship and Unemployment in the Business Cycle. Journal of International Studies, 3(1), 59-69.

Havrov, S. (2004). Modernization in the name of the empire. Socio-cultural aspects of modernization processes in Russia. Moscow: URSS.

Hofstede, G., Neuijen, B., Ohayv, D. D., \& Sanders, G. (1990). Measuring organizational cultures: A qualitative and quantitative study across twenty cases. Administrative science quarterly, 35, 286-316.

Inglehart, R., \& Baker, W. E. (2000). Modernization, cultural change, and the persistence of traditional values. American sociological review, 65, 19-51. 
Ivanov, S. (2004). Changes in the value of the paradigm of the modern Russian society in the context of social and cultural transformation. Retrieved from: http://www.superinf.ru/view.

Kluckhohn, F. R., \& Strodtbeck, F. L. (1961). Variations in value orientations.

Koudelková, P., Strielkowski, W., \& Hejlová, D. (2015). Corruption and System Change in the Czech Republic: Firmlevel Evidence. DANUBE: Law and Economics Review, 6(1), 25-46. doi: https://doi.org/10.1515/danb-20150002.

Kuklin, A. A., \& Vasilyeva, E. V. (2015). Welfare And Public Health Of The Population Of Russia: Adaptation To Economic Instability. Economy of Region/Ekonomika Regiona, 41(1), 64-76. doi: 10.17059/2015-1-6.

Kuklin, A. A. E., Zemskov, A. E., \& Nikulina, N. Y. L. (2011). Theoretical and methodological approaches to the diagnosis of the region's state material reservation system status. Economy of Region, 3, 277-280.

Novák, P., \& Popesko, B. (2014). Cost variability and cost behaviour in manufacturing enterprises. Economics \& Sociology, 7(4), 89.

Orlova, E.A. (2001). Socio-cultural prerequisites of modernization in Russia. The Library in transition, $2,7$.

Strielkowski, W., \& Weyskrabova, B. (2014). Ukrainian labour migration and remittances in the Czech Republic. Tijdschrift voor economische en sociale geografie, 105(1), 30-45. doi: https://doi.org/10.1111/tesg.12052

Stimac, H., \& Simic, M. L. (2012). Competitiveness in higher education: A need for marketing orientation and service quality. Economics \& Sociology, 5(2), 23.

Simonova, L., \& Strovsky, L. (2003). Cross-cultural interaction in international business. Moscow: UNITY-DANA.

Ustubici, A., \& Irdam, D. (2012). The Impact of Remittances on Human Development: a Quantitative Analysis and Policy Implications. Economics \& Sociology, 5(1), 74-95.

Yakovets, T. (2012). Of the driving forces of social development. The Philosophy of Economy, 4.

Zaslavskaya, T. (2011). Social actors in Russian modernization. Social Sciences, 42(4), 113-128. 